Intergenerational Negotiations on (Hetero)sexuality and Romantic Relationships : Views of Young People and Parents in Multiethnic Contexts

\title{
Peltola, Marja
}

2017

Peltola , M , Keskinen , S P , Honkasalo, M V \& Honkatukia , P M 2017 , ' Intergenerational Negotiations on (Hetero)sexuality and Romantic Relationships : Views of Young People and Parents in Multiethnic Contexts ' , Journal of youth studies , vol. 20 , no. 5 , pp. 533-548 . https://doi.org/10.1080/136

http://hdl.handle.net/10138/236676

https://doi.org/10.1080/13676261.2016.1241870

unspecified

acceptedVersion

Downloaded from Helda, University of Helsinki institutional repository.

This is an electronic reprint of the original article.

This reprint may differ from the original in pagination and typographic detail.

Please cite the original version. 


\title{
Intergenerational Negotiations on (Hetero)sexuality and Romantic
}

Relationships - Views of Young People and Parents in Multi-ethnic

\section{Contexts}

\author{
Marja Peltola
}

Suvi Keskinen

Veronika Honkasalo

Päivi Honkatukia

\begin{abstract}
This article focuses on intergenerational negotiations on young people's (1319 years) sexuality and romantic relationships in families where one or both of the parents have migrated to Finland. By utilising the theoretical framework of intersectionality and negotiability of family relationships, we seek to diversify the often problem-oriented and culture-related examinations of ethnic minority families and young people's position in them. Methodologically, we draw on interview data relating to both young people and parents. In addition to the vast heterogeneity in practices and ideals, the analysis shows that while conflicts and miscommunication between generations do occur, the intergenerational negotiations for the most part are described as consensual and based on trust. Young people are allotted considerable agency by their parents, and also demonstrate a high degree of agency, whether they are complying with their parents' views or questioning them. Their negotiations also reflect and are conditioned by their position in the hierarchies of Finnish society.
\end{abstract}

Keywords: young people, sexuality, ethnic/racialised minorities, intergenerational relationships, negotiation, intersectionality

\section{Introduction}

In today's culturally diverse European societies, young people interpret and negotiate their family and intimate relations in manifold ways. The norms concerning family life and intimate relations are ethnicised, gendered and classed: the yardstick for respectability is, by and large, White, Western and middle-class family life (Skeggs 1997). Reflecting this 
This is an Accepted Manuscript of an article published by Taylor \& Francis in Journal of Youth Studies 20 (5), 2017, available online:

https://www.tandfonline.com/doi/full/10.1080/13676261.2016.1241870

(implicit) value judgment, there is a tendency in public discussions to attach assumptions of special problems and risks to families with migrant or ethnic minority backgrounds (e.g. Foner and Dreby 2011; Peltola 2016; Phoenix and Husain 2007). Questions of gender, generation, sexuality and (in)equality are central to these assumptions - the concerns about and images of 'oppressed' minority girls are repeated in public discourses, drawing hierarchical lines between 'the equal Western families' and 'the inequal non-Western families' (Keskinen et al. 2009; Keskinen 2012a).

In this article, the focus is on intergenerational negotiations on 13-19-year-old young people's romantic relationships in families where one or both parents have migrated to Finland. We explore how the norms and negotiations related to young people's romantic relationships are described by both young people and parents, and reflect on the consensual and conflictual aspects of the negotiations. While the themes of partner selection, arranged marriages and (the alleged lack of) minority young people's autonomous choice have aroused public interest in Finland, the discussions have been framed as 'honour-related violence' emphasising questions of parental pressure and family honour (Keskinen 2009, 2012b). The active role of racialised minority youth and the effects of racialised power relations for both young people and their parents are, however, seldom focused upon. ${ }^{1}$ With the focus on the young people's agency and negotiations, we thus seek to provide knowledge on the less examined aspects of intergenerational negotiations on (hetero)sexuality.

Finland as a research location is characterised by a short history as a country of immigration and, consequently, a relatively low proportion of inhabitants with foreign backgrounds $;^{2}$ its position as one of the Nordic countries; and the rise of anti-immigration and neo-nationalist rhetoric. As in other Nordic countries, the national identity in Finland is strongly attached to notions of the egalitarian welfare state and high achievements in gender equality (Keskinen et al. 2009). While understanding gender equality as an already achieved matter masks the material differences that persist between men and women, in the debates on multiculturalism the notion of 'Nordic gender equality' functions as an exclusionary argumentative category (Honkasalo 2013). Hence, ethnic diversity and gender equality are sometimes seen as incompatible, and ethnic equality is not included in the notion of equality as self-evidently as gender equality (Honkatukia and Suurpää 2014). 
This is an Accepted Manuscript of an article published by Taylor \& Francis in Journal of Youth Studies 20 (5), 2017, available online:

https://www.tandfonline.com/doi/full/10.1080/13676261.2016.1241870

Everyday racism has been shown to be a problem in Finnish society for several decades (e.g. Rastas 2005). More recently, the rise of right-wing populism in the media and politics has changed the political landscape in Finland, rendering multiculturalism and immigration intensely debated topics in the public sphere (Keskinen 2012a). The public discussions have repercussions on the everyday lives of racialised minorities, who experience an increase in harassment and insults in public as a consequence.

In this article, we first introduce the theoretical framework underlying our analysis: the intersectionality and negotiability of social relations. We then describe the interview data and reflect on the methodological issues. The empirical part of the article, built around the notion of negotiations, is organised into two sections. The first examines consensual and trustful narratives on intergenerational negotiations; the latter entails more secretive and conflictual narratives. We conclude by assessing the findings in relation to the racialised hierarchies in Finnish society.

\section{Intergenerational negotiations and intersectionality}

The possibility of sharing experiences, thoughts and sentiments related to (future or current) romantic relationships safely within one's inner circle may be understood as a resource supporting young people's transition to adulthood. However, family life in general, and intergenerational negotiations on romantic relations in particular, have remained rather understudied areas in contemporary youth research (Côté 2014, 114-129; see however Bjerrum Nielsen \& Rudberg 2007; Madsen 2008). This applies especially to ethnic majority young people; generational relations in families with migrant or ethnic minority backgrounds have been studied at some length, mostly from the point of view of acculturation and generational differences (e.g. Portes and Zhou 1993; Suárez-Orozco and Qin 2006). While these studies have been powerful and widely-read, their focus on difference and conflict is in line with the overall problem-oriented approach towards families with migrant or ethnic minority backgrounds: generational loyalty and the positive functions of family relations have gained less attention (Peltola 2016; Foner and Dreby 2011). 
This is an Accepted Manuscript of an article published by Taylor \& Francis in Journal of Youth Studies 20 (5), 2017, available online:

https://www.tandfonline.com/doi/full/10.1080/13676261.2016.1241870

As a topic, young people's sexuality is a theme that attracts concern both at the level of society and the level of individual families. According to Madsen (2008), most parents, regardless of ethnicity, report using rules to manage their children's dating behaviours. The rules vary according to gender and age, and include different themes and degrees of strictness (ibid.). We consider it important that these rules are not understood as one-sidedly dictated, but negotiated between the generations. However, the power imbalance between parents and young people means that parents' views concerning appropriate dating practices and partners, which may be gendered and classed, have a strong impact on the young people. Singla (2006) states that among ethnic minority Danish young people, almost 70 per cent report no conflicts over this issue with their parents - 17 per cent report some conflicts and 7 per cent serious conflicts. While examining the contexts and reasons behind the serious intergenerational conflicts is important, it is noteworthy that the finding contradicts the public imageries where oppression and conflict seem to be almost self-evidently attached to the family life of ethnic minorities (ibid.).

With an intersectional approach, we seek to situate the young people and the parents in our study within a conceptual framework, where the focus is not on the (alleged) cultural differences, but on agency and its constraints. By intersectionality, we refer to the idea of social categories - generation, gender, ethnicity and 'race', among others - being mutually constitutive, simultaneously experienced dynamic processes, which structure individual agency, but in ways that may also be questioned (e.g. Brah and Phoenix 2004; Phoenix 2005). The hierarchical divides of generation and gender traverse family communities and define, to a certain extent, the roles, responsibilities and degrees of freedom of the family members. The imbalances in power mean that the potential for negative forms of social control is inherent in family life; however, the degrees of freedom are not static but continuously negotiated (e.g. Connidis and McMullin 2002.) At the same time, families are differently positioned along the racialised hierarchies at the societal level. Ethnic minority families are easily categorised as 'suspect' and inferior to white majority families; and such categorisation, or fear of it, is likely to have a bearing on how both young people and parents speak about their family life and how they seek to position it in Finnish society (Peltola 2016). For those belonging to racialised minority groups, home and family may be one of the few safe havens from experiences of racism, a source of feelings of dignity and being loved (hooks 1990, 41-49). 
This is an Accepted Manuscript of an article published by Taylor \& Francis in Journal of Youth Studies 20 (5), 2017, available online:

https://www.tandfonline.com/doi/full/10.1080/13676261.2016.1241870

Negotiations concerning sexuality, including conflicts, should not be examined as disconnected from the wider discourses on, and meanings pertaining to, family ties. Although in popular images of youth, orientation towards peers and distancing from family and parents are emphasised, young people have been found to value their familial relationships and to regard them as positive resources (Irwin 2009; Lahelma and Gordon 2008; Peltola 2016). The positive emphasis should be seen as reflecting the fundamental relationality of the self, which is hard to reconcile with the Western idea of an autonomous individual (Ribbens McCarthy 2012, 70-71): acknowledging its power does not imply bypassing or belittling the negative or coercive sides of family relationships - rather, it contributes to understanding why difficult situations may occur, and why family relationships endure despite their potentially burdening nature.

The concept of negotiation is widely used within sociological family studies, where a central part of understanding the nature of family relationships is to see them as negotiated and changing over time (e.g. Morgan 1996; Finch and Mason 1993). This also applies to generational relationships within families, in which the balance between dependence and autonomy is sought through negotiations (Connidis and McMullin 2002). The importance of negotiations may even be over-emphasised at times and risk overshadowing routines, the taken-for-granted ways of acting and the reproduction of power relations through these acts (Evertsson and Nyman 2011). According to Finch and Mason (1993, 60-61), negotiation may be explicit - expressing opinions, discussing, arguing - but also implicit, when opinions concerning preferred ways of acting are communicated to others in nonverbal ways. Implicit negotiations take place within longer timeframes and the solutions or changes are achieved incrementally, and even almost imperceptibly, by the parties (ibid.) In this article, we use the term negotiations to refer to the work of balancing ideals, practices and situational demands concerning young people's romantic relations, which takes place between young people and their parents. Additionally, in the interview situations the subject's own opinions are continuously mirrored against the (alleged or real) views of family members, which may also be interpreted as a part of the negotiation process.

\section{Data and Methods}


This is an Accepted Manuscript of an article published by Taylor \& Francis in Journal of Youth Studies 20 (5), 2017, available online:

https://www.tandfonline.com/doi/full/10.1080/13676261.2016.1241870

The article is based on interviews with young people and parents with diverse ethnic and racial identifications. The interview data sets, which were gathered in three different cities in southern Finland, are presented in Table 1. The first set of data on the young people (9 interviewees) was collected under the auspices of a project aimed at tackling 'honour-related violence', in a discussion group for young women with multi-ethnic backgrounds. The second set of data on the young people (26 interviewees) was collected at a school in a multi-ethnic residential area, where semi-structured interviews were conducted with $9^{\text {th }}$ grade pupils. All students were invited to take part on a voluntary basis, and approximately half of them decided to participate in individual or paired interviews. Due to ethical considerations, the interviewed parents were not the parents of the interviewed young people. While interviewing members of the same family produces valuable knowledge (e.g. Bjerrum Nielsen \& Rudberg 2007), the potential sensitivity of the themes related to present-day intergenerational relationships led us to choosing to limit the generational examination at the general level. The parents were recruited via non-governmental organisations and snowballing, and the interviews were conducted mostly in semi-public places such as cafés and libraries. The age scale of their children was wider than that of the interviewed young people; however, they were able to reflect their experiences during their children's teen years.

Table 1. The interview data sets.

\begin{tabular}{|l|l|l|l|}
\hline & $\mathbf{1}^{\text {st }}$ data set & $\mathbf{2}^{\text {nd }}$ data set & $\mathbf{3}^{\text {rd }}$ data set \\
\hline Target group & Young people & Young people & Parents \\
\hline Age & $13-19$ & $14-16$ & $35-70$ \\
\hline $\begin{array}{l}\text { Type and number of } \\
\text { interviews }\end{array}$ & $\begin{array}{l}4 \text { group } \\
\text { discussions } \\
\text { individual } \\
\text { interviews }\end{array}$ & $\begin{array}{l}16 \text { individual or paired } \\
\text { interviews }\end{array}$ & $\begin{array}{l}24 \text { individual } \\
\text { interviews } \\
1 \text { group interview }\end{array}$ \\
\hline $\begin{array}{l}\text { Gender and number of } \\
\text { interviewees }\end{array}$ & 9 young women & $\begin{array}{l}12 \text { young women } \\
14 \text { young men }\end{array}$ & $\begin{array}{l}14 \text { women } \\
12 \text { men }\end{array}$ \\
\hline
\end{tabular}

Both the interviewed young people and the parents identified in various ways with ethnic and racial minorities in Finland, and referred to family backgrounds relating to Iraq, Iran, 
This is an Accepted Manuscript of an article published by Taylor \& Francis in Journal of Youth Studies 20 (5), 2017, available online:

https://www.tandfonline.com/doi/full/10.1080/13676261.2016.1241870

Afghanistan, Russia, Romania, Vietnam, former Yugoslavia, Somalia, Turkey, Sudan, Morocco, Uganda, Brazil, Egypt, Yemen and Zambia. One of the young interviewees identified with the Roma community in Finland. A few of the young interviewees had migrated to Finland themselves, but most were born and raised in Finland. The interviewed parents had all migrated to Finland, and resided in the country from four to over 40 years. While having diverse ethnic and migratory backgrounds, all the interviewees shared the position in the category of 'immigrants', which is in public often understood as referring to non-Western, non-white migrants and their children, and followed by homogenising discourses and assumed deficiencies (e.g. Rastas 2005).

The themes in the young people's interviews included peer relations, school environment, residential area, experiences of racism, appearance, media consumption, family, dating/marriage and sex, and future plans. The parents' interviews were more concentrated on family life. The young people's romantic relationships, intergenerational negotiations and experiences of racism were covered in all the interviews.

The interviews should be understood as context-specific accounts reflecting the informants' experiences, but also shaped by the interview context (e.g. Heyl 2001). Group and paired interviews may lead to emphasising some interpretations while omitting topics considered sensitive by the interviewees. However, interviewing young people in pairs may also facilitate sharing sensitive issues. Apart from nine interviews with fathers, the interviews were conducted by white majority women. While age and, for the young women, gender may have been experienced as shared characteristics between the interviewees and the interviewers, the difference in ethnic and racial background may have affected the ways in which the informants chose to disclose or formulate their experiences. For instance, being interviewed by a member of the white majority may have increased the tendency to describe one's own parenting practices as conforming to (alleged) norms of the Finnish society for some parents. Moreover, due to methodological and contextual elements in the data gathering, the talk on dating concerns only heterosexual relationships. While we consider it important that heteronormativity in its various forms is analysed and deconstructed by means of research, we are bound to limit our analysis accordingly. 
This is an Accepted Manuscript of an article published by Taylor \& Francis in Journal of Youth Studies 20 (5), 2017, available online:

https://www.tandfonline.com/doi/full/10.1080/13676261.2016.1241870

The interviews were transcribed and analysed thematically. The thematic sections on dating, partnership/marriage and sexuality were further analysed in terms of intergenerational negotiations. Both inner reflections of the informants and the descriptions of the norms and practices related to romantic relationships, and how they were monitored, adhered to, bypassed or resisted in the everyday lives of the informants, were examined. The focus of the analysis is on the explicit negotiations, but the data also bring out reflections on implicit, nonverbal negotiations between the young people and the parents. The analytical conclusions were generated as a result of intensive cross-reading and comparing the thematic sections from the interviews with the young people and the parents (Strauss and Corbin 1998). One of the challenges in the analysis is that reproducing norms either in child-rearing or in the everyday life of young people may be explicitly verbalised, but also implicit or unintentional. Thus, it must be borne in mind that the accounts presented in the interviews may be based not only on open discussions but also on 'tacit' knowledge, or even assumptions about family members' conceptions.

\section{Consensual Negotiations: Individual Choice and Parental Guidance}

Most, if not all, of the interviewed young people emphasised that they were the ones to decide who they would date or marry and when they would start sexual relations. This was common for both the young women and the young men. We interpret the overarching nature of the theme as a sign of the young interviewees' internalised and active participation in the individualising discourse that is widespread in European countries. This discourse emphasises 'free will' and individual decision-making, building on the liberal tradition of autonomous individuality (e.g. Bredal 2006). In our data, however, individuality was seldom presented as totally autonomous but in varying ways as a part of social relations, family relations among others. Thus, emphasising 'one's own will' did not necessarily lead young people to oppose or criticise their parents' views on romantic relationships (see also Singla 2006).

The ways in which the young people presented their parents' views on their romantic relationships fell into three categories: (1) the parents had told the young people to do as they themselves considered best; (2) the parents expressed some wishes or requirements regarding the choice of partner or time of engaging in partnerships; (3) the parents suggested or chose 
This is an Accepted Manuscript of an article published by Taylor \& Francis in Journal of Youth Studies 20 (5), 2017, available online:

https://www.tandfonline.com/doi/full/10.1080/13676261.2016.1241870

partners for the young people. When presenting these different orientations, the young people could position themselves as agreeing, disagreeing or combining different elements in a process of reflecting on the motivations and effects of different viewpoints. In this way, they negotiated the ideals concerning partnerships and pondered their own views in relation to those of their parents.

The interviews with the parents supported such findings. While most of the parents reported they had wishes, expectations and concerns regarding their children's romantic relationships, the expectations - and the practices and guidelines that ensued - were very heterogeneous: some said they did not set any rules for their children in advance, while at the other end of the continuum were those parents who wished to suggest partners for their children. The children's ability to choose was a continuous theme in the parents' interviews as well, and even though they wished to have at least some influence over their children's behaviour, many said they acknowledged, and either accepted or worried about, the limited nature of such influence.

\section{'Doing as One Wishes'}

Several of the boys, but also some girls, revealed that one or both of their parents had stated that they could make the decisions concerning their romantic relationships as they wished. In these cases, the young people felt they had the possibility to experiment and search for a suitable partner or engage in several relations. However, not all of them were interested in dating, as focusing on school or just maturing before engaging in partnerships were considered more important. Focusing on school in particular was also encouraged by their parents, which complies with several previous findings on minority parents' tendency to emphasise the value of education (e.g. Heath et al. 2008). Refraining from romantic relationships was duly not reasoned on the grounds of parental wishes, but as one's own, responsible choice:

It's very individual how one thinks, but in my opinion it is embarrassing that I would be, like, with a male person in that kind of relationship, and then when we break up, and I see him later on, I would think about all the things we have been through and done (...) I don't believe that, now that I'm fifteen, that, well, I know that the boy will not stay with me for the rest of his life, and just because 
This is an Accepted Manuscript of an article published by Taylor \& Francis in Journal of Youth Studies 20 (5), 2017, available online:

https://www.tandfonline.com/doi/full/10.1080/13676261.2016.1241870

of that I think I don't favour people doing things like that, unless you are sure you are going to be with the other person.

[A girl with a Romanian background]

Only one of the interviewed parents, a father, stated that he would not initiate a conversation on sexuality or related issues with his son, seeing the topic as a private issue to be learned from people other than parents. The discourse used by the father may, in part, reflect his wish to distance himself from the image of 'a strict immigrant parent'; however, it may also reflect the difficulties in broaching sensitive issues in intergenerational discussions:

I: Now that your oldest son is an adolescent, do you think dating or things like that start to interest him, or at what phase?

Father: I don't know and I'm not interested - it's his life. If he wants to, he can talk with me, but I don't want to, like, pay attention to it, or make him worry. He'll find out. As for me, nobody told me anything. He'll learn. Some things people learn themselves, through experiencing. And some things they need help and support with. (...) I don't want that with him, it's like, something, his private something.

I: Like his private issue.

Father: His private issue. I don't want to. If he feels he needs me, I'm here. But I don't want to guide him, like 'hey...'.

[A father with a Somali background]

It has been pointed out that both in families of ethnic majorities (e.g. Lahelma and Gordon 2008; Madsen 2008) and in families of ethnic minorities (e.g. Espiritu 2001), girls and their behaviour tend to be subjected to parental concern and control more often than boys are, especially with regard to sexuality. The fact that the boys reported their parents not laying down any specific rules concerning romantic relationships more often than the girls did, may reflect such gendered imbalance. Many of the interviewed parents stated that the ideals they nurtured concerning romantic relationships applied to girls and boys alike. Yet, at the same time, girls were often considered more 'at risk', especially due to the possibility of pregnancy. Some parents also stated that it was important to bring daughters up to be strong, independent women who would not be victimised by men. Either way, the importance of discussing matters related to sexuality seemed to be emphasised more in the case of daughters than sons, although it did not necessarily manifest in different rules set for the children. 
This is an Accepted Manuscript of an article published by Taylor \& Francis in Journal of Youth Studies 20 (5), 2017, available online:

https://www.tandfonline.com/doi/full/10.1080/13676261.2016.1241870

\section{Parental Wishes Concerning Timing and Spousal Choice}

The largest group of young interviewees reported that their parents expressed some wishes or requirements vis-à-vis dating, choice of partner or sexual relations (cf. Madsen 2008). Timing was one of the themes in the intergenerational discussions. Some of the young people pointed out that it was both their view and their parents' wish that they would not engage in relationships, especially sexual relations, too early. What 'too early' meant varied amongst interviewees: for some it meant having relations even before their teens, for others being a minor or unmarried, and for still others being immature and unable to commit oneself to family life with children. The 'right age' for committing to a relationship has proved to be a common theme pondered by young people in Finland regardless of their ethnic background (e.g. Ketokivi 2005). The young interviewees in our study negotiated the 'right age' in relation to their parents' views, but also in relation to notions they perceived as common in their peer groups and other contexts. While many of them shared their parents' views, others openly questioned them:

Girl 1: They [the parents] say that only when you are over 18 can you [have a romantic relationship], so that, 'you are going to lose your reputation if you go with somebody'.

Girl 2: My mum, for her part, is like, then you wouldn't be able to concentrate on school, so that's why she doesn't want it yet. (...)

I: Do you agree with your parents?

Girl 1: Not at all.

I: ... on dating?

Girl 2: Erm. I think it's my own business.

[Two girls with Vietnamese backgrounds]

Hence, the young interviewees were not always convinced by the reasons their parents gave for refraining from romantic relationships - such as preventing 'a bad reputation' or the importance of school - but positioned themselves in opposition to their parents' views. Different viewpoints did not, however, necessarily result in conflicts. Taking the opposing position may also be interpreted as refuting the racialising view of 'immigrant girls' as passive objects of their parents' authority. 
This is an Accepted Manuscript of an article published by Taylor \& Francis in Journal of Youth Studies 20 (5), 2017, available online:

https://www.tandfonline.com/doi/full/10.1080/13676261.2016.1241870

Another common theme in the interviews related to spousal choice. According to the young people, their parents often expressed the wish for the boy- or girlfriend or the future spouse to be 'a decent person', 'decency' manifesting in avoidance of bad habits (smoking, drinking, criminality, bad sexual reputation) and sometimes also in coming from 'a good family', known to be respectable (cf. Berg and Peltola 2015). They talked about knowing that their parents preferred a member of the same ethnic or religious group - a request many of them were prepared to follow. Such a choice was reasoned not only based on the parents' views, but also considering practical questions related to interaction in the partnership: shared ethnic or religious identifications were considered to enhance the understanding between the partners and therefore to facilitate good everyday relations.

Such a preference was confirmed in the interviews with the parents, some of whom stated, even vehemently, that they hoped their children would find a spouse within their ethnic or religious group. The reasons given were similar to those practical and value-based reasons expressed by the young people, yet the parents were also concerned about their children's and their grandchildren's - assimilation and 'losing their roots':

Father: If my children have children with someone from another nationality, my grandchildren won't be totally Albanian. (...) Preserving that identity is important.

I: Is it more important than love?

Father: Well, no, if they fall in love, then that's that. But it is my wish that when the child is going to fall in love, why not fall in love with an Albanian. I don't understand why not. (...) Even if she doesn't like the first Albanian boy she gets to know, she can get to know another, and another, until she finds the one.

[A father with an Albanian background]

Despite the strong preference for endogamy, the father above understands 'love' as a force potentially transcending his beliefs and wishes, and 'falling in love' as being in his children's hands, not in his. However, even 'falling in love' seems, in the quote, to be something that may be influenced, channelled, or even coaxed, to a certain extent.

Some of the young people stated that it was customary in their family or ethnic community to get married only after one's parents had suggested a suitable partner. Notably, for those young 
This is an Accepted Manuscript of an article published by Taylor \& Francis in Journal of Youth Studies 20 (5), 2017, available online:

https://www.tandfonline.com/doi/full/10.1080/13676261.2016.1241870

people who were willing to comply with such a practice, it was not seen as contradicting one's own agency and the possibility to choose. For instance, two boys who approved of the practice of arranged marriage, emphasised that they were able to override their parents' suggestions about prospective partners:

Boy 1: If he [young person] says "no", then nothing happens, they are not getting married, then they say that we don't want it.

Boy 2: Yes, they'll approve if we say that we don't want to, for example if they say that with that one, we go and get to know their parents and like that. If I say that I don't want to get married to this person, they say OK.

[Two boys with Kurdish backgrounds]

Similarly, a Kurdish mother, when describing the customary and anticipated process of arranging a marriage, grants a degree of freedom of choice to the young people in question, both before and after the marriage contract:

The boy needs to come to ask the family, "I'd like to marry your daughter, I am like this, these are my parents, their name is good and we live, for example, in this place, this city. You can ask who we are, what kind of family we are. I wish to ask your daughter [to be my wife]." (...) There are many different things, he cannot smoke, cannot drink alcohol. Then, if he's a good boy, I ask my daughter: "All this is in front of you, do you want to get married?". And if she says I do, they can, that's all. Then they agree. And they can divorce, afterwards, if she doesn't love him.

[A mother with a Kurdish background]

The mother's reference to 'a good boy' also highlights how the complex conceptions of respectability, constructed in the intersection of gender, class and ethnicity, shape the parental wishes.

\section{Mutual Trust in Consensual Negotiations}

Generally speaking, commonalities concerning romantic ideals can be observed in the interviews with both the young people and the parents. What was common to the heterogeneous accounts described above was that while the positions of both groups varied, achieving common ground did not require bitter fights between generations, but rather, 
This is an Accepted Manuscript of an article published by Taylor \& Francis in Journal of Youth Studies 20 (5), 2017, available online:

https://www.tandfonline.com/doi/full/10.1080/13676261.2016.1241870

explicit and implicit negotiations, mutual trust and ongoing dialogue. A young man who portrayed his parents as somewhat stricter than himself regarding dating still emphasised trustful relations as being paramount: although parents had their own views, they would try to support their children and trust their choices as being reasonable.

But they still support the young person's thoughts, because they don't want to hurt them, or to be nasty to them. But still, if they trust [the young person], they don't complain at all, if they trust their own children and believe they have managed to teach them to behave.

[A boy with a Somalian background]

This echoes the view emerging from the interviews conducted with the parents that conversation - verbal guidance - was their first and foremost means of influencing young people's views and practices concerning dating. Like the father below, many said that they had repeated conversations on the theme, but apart from that, they could only trust that their children would make responsible choices.

I often speak [to the children] about the consequences, that if you go and have sex, then you need to expect something which you don't like. In the future, it may be that it ruins your whole life, so that's why it is for us in the religion, for us Muslims, that having sex before marriage is forbidden. So I speak about these things with them, yes.

\section{[A father with a Moroccan background]}

Thus teaching 'rights and wrongs' and pointing out the risks was the parents' duty, but the concrete decision-making in the everyday lives of the young people was not considered to be in the parents' hands. Some parents also mentioned that they could trust their children to act in a responsible way and not to abuse the freedom they were given because they felt that they knew them and their moral values so well. The feeling of mutual trust therefore made the generational negotiations easier, and in some cases even resulted in greater freedom for the young people than the parents considered customary. At the same time, trust is closely intertwined with young people's socialization and internalizing the core values cherished by the parents. Thus, the 'free choice' emphasized in the data is relative by nature and takes place within certain limits. 
This is an Accepted Manuscript of an article published by Taylor \& Francis in Journal of Youth Studies 20 (5), 2017, available online:

https://www.tandfonline.com/doi/full/10.1080/13676261.2016.1241870

\section{Secrets and Intergenerational Conflicts}

While a significant proportion of the intergenerational negotiations recorded in the data seemed to be consensual and built on trust, there were also examples of generational miscommunication and conflict. Some of these narratives appeared to be related to difficulties in communication between young people and their parents, and others to differences in ways of thinking or contradictions between ideals and the complex reality. While some interviewees - both young people and parents - reported that they had open and communicative relationships, others had discussed matters related to sexuality very little or not at all. Discussions were also gendered to an extent, as some of the girls said they found it easier to discuss issues related to sexuality with their mothers than their fathers.

For those young people who presumed their parents would not accept dating or their chosen partner, selective revealing or concealment of the romantic relationships was a strategy used for gaining influence in regard to dating, while simultaneously avoiding entering into (assumed or real) conflicts with parents. Several young interviewees spoke about either themselves or someone they knew having a clandestine relationship. Often they engaged in the relationships through the Internet, not necessarily meeting but chatting online, thus confirming the research findings on the importance of social media for young people in maintaining, experimenting with and playing out intimate relationships (Crofts et al. 2015, 131-133). At other times, the young people may meet and date without letting parents know, or just let the parent that they consider to be more 'relaxed' in on the dating. In these cases, the relationships are semi-public: certain people know about them, while others are kept in the dark. It was often the young women who wished to conceal the relationship from their parents, in order to pre-empt conflicts or to delegitimise their parents' authority without openly questioning it.

In the young people's narratives, however, it seems that some parents are aware of the selective revealing practices, or turn a blind eye to practices they do not totally condone but prefer not to argue about. Other parents had asked their children to be open about dating when topical, perhaps because they realised the risks entailed in the issue being concealed. Thus, maintaining a trustful relationship may be seen as more worthy than rigorously embracing 
This is an Accepted Manuscript of an article published by Taylor \& Francis in Journal of Youth Studies 20 (5), 2017, available online:

https://www.tandfonline.com/doi/full/10.1080/13676261.2016.1241870

ideals and norms. Such an interpretation was supported by the parents' interviews, in which some interviewees spoke about secretive dating practices and saw them as a consequence of expecting rules to be adhered to too strictly. In a group interview, two mothers brought up the fact that parents should not impose rules too strictly, as it would cause young people emotional stress:

I: So a boy may have a girl as his friend? Or [vice versa]...

Mother 1: He may, of course. But he cannot have a serious relationship or such like as it is forbidden.

Mother 2: But now our children for sure... (laughs, suggests that the children are having relationships anyway)

Mother 1: Secretly, children may do a lot. A child, if he or she wants to keep it secret, he or she can do anything. And if the mother sees this, she shouldn't put too much pressure on the child. [Mother 2: It's good, I agree.] In my opinion, one should not press too much. It makes the child's head spin. (...) If too many things are forbidden, the child does more in secret.

[Two mothers, with an Egyptian and a Turkish background]

However, the practice of concealing romantic relationships was not necessarily confined to those who communicated with their parents less or who had stricter rules. For instance, the two girls below, despite joking about men and dating with their mother, stated that they probably would not let their parents know if they were actually dating. While they took their parents' wishes about focusing on school seriously, following parental guidance in matters related to dating was not self-evident:

Girl 2: Sometimes I joke to my mum that I should get that kind of [a boyfriend], if someone who passes by is handsome, then I'm like 'he is my future boyfriend' [laughs].

I: What does your mother say about that?

Girl 2: She only laughs, 'don't even dream about that'. But she does not...

Girl 1: My mum has said, you know, whatever, but her opinion is that I should finish school first. She says I can decide when I choose a man, but first I will need to finish school.

I: If you have a boyfriend, or you are dating, do you keep it to yourself or do you tell your parents about it?

Girl 1: I will only tell my friends.

Girl 2: I don't know, maybe I would do the same.

[Two girls, with Kosovan and Iraqi backgrounds] 
This is an Accepted Manuscript of an article published by Taylor \& Francis in Journal of Youth Studies 20 (5), 2017, available online:

https://www.tandfonline.com/doi/full/10.1080/13676261.2016.1241870

Although the parents expressed rather clear views on the expected 'appropriate' sexual conduct of their children, some of them also shared experiences of their children's behaviour not matching these expectations. These narratives clearly show that even though parental norms and expectations have an influence on young people's lives, they do not determine the lived realities - neither the behaviour and actions of the young people nor the reactions of the parents. Yet, in the interviews with the parents, no major, long-term conflicts were reported. Instead, while the parents described being surprised or even shocked when their children's behaviour conflicted with the norms, adjusting to the situation and maintaining supportive relationships was the way they had chosen to act. Understanding such reactions was not, however, fully self-evident: as a mother with an Iranian background describes below, her own mother saw her and her husband's reaction as 'peculiar':

With one of our kids we had, much later, things happened, that even my mother thought that we as parents reacted in quite a peculiar way. Although it was a great shock and a source of sorrow for me and my husband. (...) We don't really consider it a good thing that one is having sexual relations before marriage. Then, this kid suddenly let us know that she has this kind of a situation and she's pregnant. And it is such a severe shock to someone who thinks in a totally different way. And we considered what we needed to do. And we thought and we thought that the most important thing is that, because, everybody makes mistakes in life. This child herself feels that this wasn't right, and this boy, he felt too that it was wrong. And they have experienced it and suffered. So at this age, we shouldn't do anything else but show love and empathy, and support them to move forward. (...) But at the time it was so painful, I didn't sleep for a week, it was terribly hard.

[A mother with an Iranian background]

While conflictual relationships between parents and young people in minority ethnic families are often highlighted in research (e.g. Espiritu 2001, 2008; Suárez-Orozco and Qin 2006), the example shows that constructive responses and continued support are also possible courses of action for parents in a conflict situation.

In addition to such positive examples, the data included one case where an interviewed girl was clearly worried about not being able to decide for herself when it came to her future marriage. Her father had said he would try to find a husband for her in Kosovo, but the interviewee did not agree with this decision. According to the interviewee, negotiations over 
This is an Accepted Manuscript of an article published by Taylor \& Francis in Journal of Youth Studies 20 (5), 2017, available online:

https://www.tandfonline.com/doi/full/10.1080/13676261.2016.1241870

what to do seemed to be ongoing between a mediating mother, a determined father and a determined daughter. The mother sided with her daughter, saying she could marry for love, but at times also argued the case for finding someone from their former home country.

I: What do you think, will you let your parents choose your boyfriend? Boy 2: Are you going to...?

Girl 1: Not in a million years! My father has said many times that he would search for a nice man for his daughter in Kosovo. Then I'm raging like hell to my mum all the time, since I don't dare to rage to my father, that fucking he's not going to search for a boy for me, I'm definitely going to find one myself. And then, like, they say that it would be good to find a man in Kosovo. (...) What I want is a Kosovan man from Finland.

Boy 2: ... it's really difficult then.

Girl 1: Well, I told my mum that then he wouldn't know Finnish. I would need to support him financially here, he wouldn't have a job, he wouldn't have anything, so I'm really not going to.... [mother says] it doesn't matter, he will learn when he comes here. [...] This culture is like this. Yeah. But my mum has told me that I can find a man by myself, that I can find someone I love.

[A girl with a Kosovon background, and a boy with a Kurdish background]

The interviewed young woman strongly opposed her father, but also sought to avoid an open conflict with him. While she agreed to follow the family norms by finding a partner from among the same ethnic minority group, she sought to broaden the scope of these normative practices by emphasising her own role in finding her future partner in Finland. Hence, she was not aiming for a total break from the family norms, but to moderate them in part.

\section{Young People's Agency, Racialised Hierarchies and Intergenerational Negotiations}

We have sought to analyse the ways in which intergenerational negotiations on young people's romantic relationships figure in interviews with both young people and parents with various minority ethnic backgrounds in Finland. What is evident is the great heterogeneity in the data with regard to both the views on appropriate ways to engage in romantic relationships and the practices through which they are negotiated within the families. Yet themes common to the differing discourses can also be detected. 
This is an Accepted Manuscript of an article published by Taylor \& Francis in Journal of Youth Studies 20 (5), 2017, available online:

https://www.tandfonline.com/doi/full/10.1080/13676261.2016.1241870

Young people's autonomy and ability to choose were strongly emphasised throughout the data - although their limits were understood in different ways, also within generations. When presenting themselves as individuals making choices, the young people may position themselves as complying with or opposing the views of their parents, or combine elements of their parents' views with views adopted elsewhere (see also Singla 2006). Parental expectations, norms and ideals thus existed alongside the discourses emphasising the young people's 'free choice'. Such a finding in itself underlines the multifaceted nature of parental guidance and control, and the fact that the concrete lived situations were not determined by the ideals and norms, but formed through negotiations. At a more analytical level, the data also highlight the relational nature of the young people's decision-making and relativity of 'free choice'. Despite the discursive emphasis placed on individual choice, the feelings of loyalty and responsibility were in many ways interwoven with decisions on whether to engage in or refrain from romantic relationships and in the negotiation practices with parents. While young people derive their ideas concerning romantic relationships from multiple sources, internalizing at least part of the parental values also have a role in how intergenerational trust and young people's responsibility was seen in the interviews.

The intergenerational relationships in all families are conditioned and shaped by the racialised, gendered and classed power relations of the societal context. The stereotypical, problem-oriented and racialising public imagery on ethnic minority families, in which the parents are represented as patriarchal and oppressive and the young people as helpless victims, forms a background through which ethnic minority youth's family relationships are often seen and heard (Honkasalo 2013). Our findings problematise such assumptions at multiple levels. First, the emphasis placed on individuality and 'free choice' - while reflecting the ubiquitous nature of individualising discourses - may be interpreted as a discursive strategy to maintain distance from the racialised stereotypes of patriarchalism, traditionalism and strict generational divides. Second, our data show that differences of opinion, miscommunication, tension and conflicts occur, but trust, loyalty and the wish to avoid hurting family members' feelings are also strongly present in the intergenerational negotiations. Third, the data illustrate the strong agency that the young people have both regarding their relationships with their parents and the negotiation on sexuality and romantic relationships more broadly. Depending on the situation, the young people may bypass the 
This is an Accepted Manuscript of an article published by Taylor \& Francis in Journal of Youth Studies 20 (5), 2017, available online:

https://www.tandfonline.com/doi/full/10.1080/13676261.2016.1241870

control as well as make active decisions to conform or resist. They may represent their conformity with the cultural or religious tradition as an active choice, or as a way to avoid hurting their parents' feelings. They may also fiercely resist their parents' imposition of norms and arranged marriage practices, engage in criticism from their own position and seek alternatives that would guarantee them enough decision-making power to make the solution acceptable to them. The parents, for their part, also show agency, not only in terms of guidance and control of the young generation, but also in terms of adjusting, seeking a compromise, and resisting the image of 'the strict immigrant parent'. The data also reveal the fact that parents are not unanimous on these matters; instead, they may disagree, have different views or at least speak in different ways to the young people at different times.

Lastly, with our choice of focus, we have endeavoured to reaffirm the significance of the family and intergenerational relations for young people: family relations are not (only) 'intrafamilial' issues, but intertwine with young people's life courses, peer relations, decisionmaking as well as public discourses in many ways. Viewing young people's narratives in relation to parents' narratives sheds further light on the interdependencies and relationality in the lives of young people. We argue that the themes highlighted in the data - individuality and relationality, intergenerational loyalty, negotiation and conflict - are relevant not only for young people representing ethnic minorities, but for all young people. Young people's family relations have remained a rather marginal theme within both youth and family research. However, their stronger analysis from the perspective of youth research would likely provide a valuable contribution to the way in which we perceive family life and young people's position in it.

\footnotetext{
${ }^{1}$ Racialisation refers to the processes through which people are categorised and positioned in relation to 'race' and ideas related to 'races'. While they may be also contested, these processes often reinforce power hierarchies and influence the everyday life and living conditions of both individuals and groups (Phoenix 2005).

${ }^{2}$ In $2014,5.9 \%$ of the population had 'a foreign background'; the percentage is, however, higher in the cities of Southern Finland (for instance $13.8 \%$ in Helsinki in 2014).
}

\section{References}


This is an Accepted Manuscript of an article published by Taylor \& Francis in Journal of Youth Studies 20 (5), 2017, available online:

https://www.tandfonline.com/doi/full/10.1080/13676261.2016.1241870

Bjerrum Nielsen, Harriet, and Rudberg, Monica. 2007. Fun in Gender - Youth and Sexuality, Class and Generation. NORA - Nordic Journal of Feminist and Gender Research 15 (2-3): $100-113$.

Brah, Avtar, and Ann Phoenix. 2004. Ain't I A Woman? Revisiting Intersectionality. Journal of International Women's Studies 5(3): 75-86.

Bredal, Anja. 2006. 'Vi er jo en familie'. Arrangerte ekteskap, autonomi og fellesskap blant unge norsk-asiater. Oslo: Unipax.

Connidis, Ingrid, and Julie McMullin. 2002. Sociological Ambivalence and Family Ties: A Critical Perspective. Journal of Marriage and Family 64(3): 558-567.

Côté, James. 2014. Youth Studies. Fundamendal Issues. Basingstone: Palgrave MacMillan.

Crofts, Thomas, Murray Lee, Alyce McGovern, and Sanja Milivojevic. 2015. Sexting and Young People. New York: Palgrave MacMillan.

Espiritu, Yen Le. 2001. 'We Don't Sleep Around Like White Girls Do': Family, Culture, and Gender in Filipina American Lives. Signs: Journal of Women in Culture and Society 26(2): 415-440.

Evertsson, Lars and Charlott Nyman. 2011. Unpacking the Concept of Negotiation in Research on Couples and Families. International Journal of Humanities and Social Science 1(10): 70-76.

Finch, Janet and Jennifer Mason. 1993. Negotiating Family Responsibilities. London: Routledge.

Foner, Nancy and Joanna Dreby. 2011. Relations between the generations in immigrants' families. Annual Review of Sociology 37:545-564.

Heath, Anthony, Catherine Rothon, and Elina Kilpi. 2008. The Second Generation in Western Europe: Education, Unemployment, and Occupational Attainment. Annual Review of Sociology 34:211-235.

Heyl, Barbara Sherman. 2001. Ethnographic Interviewing. In Handbook of Ethnography, edited by Paul Atkinson, Amanda Coffey, Sara Delamot, John Lofland, and Lyn Lofland, 369-383. London: Sage.

Honkasalo, Veronika. 2013. 'Save the Girls!' Gender Equality and Multiculturalism in Finnish Youth Work Contexts. Girlhood Studies 6(2): 47-64.

Honkatukia, Päivi, and Leena Suurpää. 2014. Generational Negotiations on Young Men's Criminality and Ethnic Hierarchies. In Migration and Integration from a Nordic Perspective, edited by Paul Van Aerschot, 187-198. Farnham: Ashgate.

hooks, bell. 1990. Yearning. Race, Gender, and Cultural Politics. Boston: South End. 
This is an Accepted Manuscript of an article published by Taylor \& Francis in Journal of Youth Studies 20 (5), 2017, available online:

https://www.tandfonline.com/doi/full/10.1080/13676261.2016.1241870

Irwin, Sarah. 2009. Family contexts, norms and young people's orientations: researching diversity. Journal of Youth Studies 12(4): 337-354.

Keskinen, Suvi. 2009. 'Honour-related violence' and Nordic Nation-building. In Complying with Colonialism. Gender, Race and Ethnicity in the Nordic Region. Edited by Suvi Keskinen, Salla Tuori, Sari Irni and Diana Mulinari. Farham: Ashgate.

Keskinen, Suvi, Salla Tuori, Sari Irni, and Diana Mulinari, eds. 2009. Complying with Colonialism. Gender, Race and Ethnicity in the Nordic Region. Farnham: Ashgate.

Keskinen, Suvi. 2012a Limits to Speech? The Racialised Politics of Gendered Violence in Denmark and Finland. Journal of Intercultural Studies 33(3): 261-274.

Keskinen, Suvi. 2012b. Transnational Influences, Gender Equality and Violence in Muslim Families. In Whiteness and Postcolonialism in the Nordic Region. Exceptionalism, Migrant Others and National Identities, edited by Kristín Loftsdottir, and Lars Jensen, 73-88.

Farnham: Ashgate.

Ketokivi, Kaisa. 2005. Aikuistumisen ja perheen perustamisen ristiriidat pidentyneessä nuoruudessa. In Polkuja ja poikkeamia - Aikuisuutta etsimässä, edited by Sinikka Aapola, and Kaisa Ketokivi, 100-137. Helsinki: Nuorisotutkimusseura.

Lahelma, Elina and Tuula Gordon. 2008. Resources and (in(ter))dependence. Young people's reflections on parents. Young 16(2): 209-226.

Madsen, Stephanie. 2008. Parents' Management of Adolescents' Romantic Relationships Through Dating Rules: Gender Variations and Correlates of Relationship Qualities. Journal of Youth and Adolescence 37(9): 1044-1058.

Morgan, David HJ. 1996. Family Connections. An Introduction to Family Studies. Cambridge: Polity Press.

Peltola, Marja. 2016. Respectable families. Discourses on family life, ethnic hierarchies and social positioning. Ethnicities 16(1): 22-39.

Phoenix, Ann. 2005. Remembered Racialization: Young People and Positioning in Different Understandings. In Racialization. Studies in Theory and Practicem, edited by Karim Murji and John Solomos, 103-122. Oxford: Oxford University Press.

Phoenix, Ann and Fatima Husain. 2007. Parenting and ethnicity. York: Joseph Rowntree Foundation.

Portes, Alejandro and Min Zhou. 1993. The New Second Generation: segmented assimilation and its variants. Annals of the American Academy of Political and Social Science 539(1): 7496.

Rastas, Anna. 2007. Racializing Categorization among Young People in Finland. YOUNG 13(2): 147-166. 
This is an Accepted Manuscript of an article published by Taylor \& Francis in Journal of Youth Studies 20 (5), 2017, available online:

https://www.tandfonline.com/doi/full/10.1080/13676261.2016.1241870

Ribbens McCarthy, Jane. 2012. The powerful relational language of 'family': togetherness, belonging and personhood. The Sociological Review 60(1): 68-90.

Singla, Rashmi. 2006. Intimate Partnership Formation and Intergenerational Relationships among Ethnic Minority Youth in Denmark. Outlines - Critical Practice Studies 8(2): 76-97.

Skeggs, Beverley. 1997. Formations of Class and Gender. Becoming Respectable. London: Sage.

Strauss, A, and J Corbin. 1998. Basics of Qualitative Research: Techniques and Procedures for Developing Grounded Theory. Thousand Oaks: Sage.

Suárez-Orozco, Carola and Desirée Baolian Qin. 2006. Gendered Perspectives in Psychology: Immigrant Origin Youth. International Migration Review 40(1), 165-198. 